\title{
Bridging the gap between coordinate- and keyword- based search of neuroscientific databases by UMLS-assisted semantic keyword extraction
}

\author{
Wilkowski, Bartlomiej; Szewczyk, Marcin Marek; Hansen, Lars Kai
}

Published in:

Neurolmage

Publication date:

2009

Document Version

Early version, also known as pre-print

Link back to DTU Orbit

Citation (APA):

Wilkowski, B., Szewczyk, M. M., \& Hansen, L. K. (2009). Bridging the gap between coordinate- and keywordbased search of neuroscientific databases by UMLS-assisted semantic keyword extraction. In Neurolmage: Supplement 1 (Vol. 47)

\section{General rights}

Copyright and moral rights for the publications made accessible in the public portal are retained by the authors and/or other copyright owners and it is a condition of accessing publications that users recognise and abide by the legal requirements associated with these rights.

- Users may download and print one copy of any publication from the public portal for the purpose of private study or research.

- You may not further distribute the material or use it for any profit-making activity or commercial gain

- You may freely distribute the URL identifying the publication in the public portal 


\title{
Bridging the gap between coordinate- and keyword- based search of neuroscientific databases by UMLS-assisted semantic keyword extraction
}

\author{
Bartłomiej Wilkowski, Marcin Marek Szewczyk, Lars Kai Hansen \\ Center for Integrated Molecular Brain Imaging \\ Technical University of Denmark, DTU Informatics \\ bw@imm.dtu.dk, msz@imm.dtu.dk, lkh@imm.dtu.dk
}

\section{Introduction}

The rapid growth of the neuroimaging literature brings the demand for integration, organization and dissemination among a highly interdisciplinary community of researchers, see e.g. (Wager, Lindquist \& Kaplan 2007). Since functional localization in brain is normally represented in form of stereotaxic coordinates, it can be used directly in the process of retrieving related literature in a given functional context by the measure of coordinate distance. Current neuroimaging databases which provide coordinate-based search capabilities (Brede Database, BrainMap) contain relatively small number of publications (Szewczyk 2008), therefore an interconnection with more comprehensive bibliographical databases can extend the results pool. Recently, the BredeQuery plug-in for SPM pipeline was presented as a tool which enables coordinate-based querying of the Brede Database directly from SPM (Wilkowski, Szewczyk, Rasmussen, Hansen \& Nielsen 2009). As an extension of the current plugin's functionality, we propose methods for integration of the Brede Database with the almost complete medical publication database - PubMed (http://pubmed.org).

\section{Methods}

The first step towards the integration of PubMed with the BredeQuery plug-in is efficient keyword extraction from abstracts returned by the Brede Database (Nielsen 2003) after coordinate-based searching. The extracted keywords can be later used for modelling PubMed's query. Keywords are concatenated using OR, AND logical operators. We are developing Semantic KEyword Extraction Pipeline for Medical Documents (SKEEPMED) web service for mapping terms from abstracts to the UMLS Metathesaurus concepts using the MetaMap08 program (Aronson 2001). As we focus on the neuroscientific literature, we extract two types of keywords: brain parts (brain_part) and other significant domain terms (term). The final query is constructed with the following structure: (brain_part_1 OR brain_part_2 OR ...) AND (term_1 AND term_2 AND ...).

\section{Results}

We queried the Brede Database with a test coordinate in Talairach (Talairach \& Tournoux 1988) space $(-8,1,9)$, which relates to the thalamus brain region. The highest ranked experiment returned by the database belongs to article "Neuroanatomical Correlates of Happiness, Sadness, and Disgust" by Richard D. Lane et al. (1997), in the following referred to as the "source". "Source" contains description of 10 experiments with a total of 90 reported coordinates. The following keywords were extracted by SKEEPMED: brain_part keywords: cerebral cortex, thalamus, insula, frontal lobe ; term keywords: disgust, sadness, happiness, emotion. The PubMed query based on these keywords returned the "source" and 20 additional articles closely related to the topic of "source". We inspected only articles published later than "source" (16), 8 of which do not contain any experiment coordinates. To investigate the relevance of the remaining 8 articles, we compared spatial closeness of experiment coordinates from these 8 articles with the "source" experiments by querying Brede Database. Experiment coordinates from 6 of them are located in a close neighbourhood of "source's" experiments. Results are presented in Table 1. 


\begin{tabular}{|c|c|c|c|}
\hline$\#$ & 1. PubMed Article & 2. Year & $\begin{array}{l}\text { 3. Position in } \\
\text { Brede Database } \\
\text { search }\end{array}$ \\
\hline 1 & $\begin{array}{l}\text { Neural correlates of heart rate variability during emotion } \\
\text { (Lane RD et al.) }\end{array}$ & 2009 & $\# 1(70 \%)$ \\
\hline 2 & $\begin{array}{l}\text { Beyond disgust: impaired recognition of negative emotions } \\
\text { prior to diagnosis in Huntington's disease (Johnson SA et } \\
\text { al.) }\end{array}$ & 2007 & $\begin{array}{l}\text { no coordinates } \\
\text { reported }\end{array}$ \\
\hline 3 & $\begin{array}{l}\text { Disgust and happiness recognition correlate with anteroven- } \\
\text { tral insula and amygdala volume respectively in preclinical } \\
\text { Huntington's disease (Kipps CM et al.) }\end{array}$ & 2007 & $\# 3(20 \%)$ \\
\hline 4 & $\begin{array}{l}\text { An event related functional magnetic resonance imaging } \\
\text { study of facial emotion processing in Asperger syndrome } \\
\text { (Deeley Q et al.) }\end{array}$ & 2007 & - \\
\hline 5 & $\begin{array}{l}\text { Neurophysiological correlates of induced discrete emotions } \\
\text { in humans: an individually oriented analysis (Aftanas LI et } \\
\text { al.) }\end{array}$ & 2006 & $\begin{array}{l}\text { no coordinates } \\
\text { reported }\end{array}$ \\
\hline 6 & $\begin{array}{l}\text { Neurophysiological correlates of induced discrete emotions } \\
\text { in humans: an individual analysis (Aftanas LI et al.) }\end{array}$ & 2004 & $\begin{array}{l}\text { no coordinates } \\
\text { reported }\end{array}$ \\
\hline 7 & $\begin{array}{l}\text { Functional neuroanatomy of emotions: a meta-analysis } \\
\text { (Murphy FC et al.) }\end{array}$ & 2003 & $\begin{array}{l}\text { no coordinates } \\
\text { reported }\end{array}$ \\
\hline 8 & $\begin{array}{l}\text { Common and distinct neural responses during direct and } \\
\text { incidental processing of multiple facial emotions (Winston } \\
\text { JS et al.) }\end{array}$ & 2003 & $\# 9(20 \%)$ \\
\hline 9 & $\begin{array}{l}\text { A preferential increase in the extrastriate response to sig- } \\
\text { nals of danger (Surguladze SA et al.) }\end{array}$ & 2003 & $\# 1(10 \%)$ \\
\hline 10 & $\begin{array}{l}\text { Impaired facial emotion recognition in early-onset right } \\
\text { mesial temporal lobe epilepsy (Meletti S et al.) }\end{array}$ & 2003 & $\begin{array}{l}\text { no coordinates } \\
\text { reported }\end{array}$ \\
\hline 11 & $\begin{array}{l}\text { Age-related differences in brain activation during emotional } \\
\text { face processing (Gunning-Dixon FM et al.) }\end{array}$ & 2003 & - \\
\hline 12 & $\begin{array}{l}\text { An fMRI study of facial emotion processing in patients with } \\
\text { schizophrenia (Gur RE et al.) }\end{array}$ & 2002 & $\# 2(60 \%)$ \\
\hline 13 & $\begin{array}{l}\text { Functional neuroanatomy of emotion: a meta-analysis of } \\
\text { emotion activation studies in PET and fMRI (Phan KL et } \\
\text { al.) }\end{array}$ & 2002 & $\begin{array}{l}\text { no coordinates } \\
\text { reported }\end{array}$ \\
\hline 14 & $\begin{array}{l}\text { Deficits in recognition of emotional facial expression are } \\
\text { still present in alcoholics after mid- to long-term abstinence } \\
\text { (Kornreich C et al.) }\end{array}$ & 2001 & $\begin{array}{l}\text { no coordinates } \\
\text { reported }\end{array}$ \\
\hline 15 & $\begin{array}{l}\text { Activation of anterior paralimbic structures during guilt- } \\
\text { related script-driven imagery (Shin LM et al.) }\end{array}$ & 2000 & $\# 7(50 \%)$ \\
\hline 16 & $\begin{array}{l}\text { Perception of emotion in frontotemporal dementia and } \\
\text { Alzheimer disease (Lavenu I et al.) }\end{array}$ & 1999 & $\begin{array}{l}\text { no coordinates } \\
\text { reported }\end{array}$ \\
\hline
\end{tabular}

Table 1: Results of spatial closeness comparison between experiments from PubMed retrieved articles and "source". Column 3. shows the position of the best-matched "source's" experiment in the results list returned by Brede Database when querying a test article experiment coordinates. In the parentheses the percentage of matched "source's" experiments found in top 20 Brede Database results is shown.

\section{Conclusions}

Current neuroimaging databases are limited and we have discussed a new way of enhancing their usability. We use the highly refined information in the Brede database to form an informed query into the literature at large. The case story showed the viability of the approach and gives us confidence that coordinate based search can be combined with language processing for a productivity enhancing tool for all neuroimagers. Current work concerns quantitative testing of the method. 


\section{References}

Aronson, A. (2001), 'Effective Mapping of Biomedical Text to the UMLS Metathesaurus: The MetaMap Program', JOURNAL OF BIOMEDICAL INFORMATICS 35, 17-21.

Nielsen, F. A.. (2003), The Brede database: a small database for functional neuroimaging, in 'NeuroImage', Vol. 19, Elsevier. Presented at the 9th International Conference on Functional Mapping of the Human Brain, June 19-22, 2003, New York, NY.

Szewczyk, M. M. (2008), Databases for neuroscience, Master's thesis, Technical University of Denmark.

Talairach, J. \& Tournoux, P. (1988), Co-planar Stereotaxic Atlas of the Human Brain, Thieme Medical Publisher Inc, New York.

Wager, T. D., Lindquist, M. \& Kaplan, L. (2007), 'Meta-analysis of functional neuroimaging data: current and future directions', Social Cognitive and Affective Neuroscience 2(2), 150-158.

Wilkowski, B., Szewczyk, M. M., Rasmussen, P. M., Hansen, L. K. \& Nielsen, F. A. (2009), Coordinatebased meta-analytic search for the SPM neuroimaging pipeline - The BredeQuery plugin for SPM5, in 'HEALTHINF 2009'. 